ORIGINAL RESEARCH ARTICLE

\title{
Contraceptive Use, Unwanted Pregnancies and Abortions among Hairdressers in Ibadan, Southwest Nigeria
}

\author{
Folashade O. Omokhodion ${ }^{1}$ and Mary O. Balogun ${ }^{1}$ \\ Department of Community Medicine, College of Medicine, University of Ibadan, Nigeria ${ }^{1}$ \\ *For Correspondence: Email: fomokhodion@yahoo.com
}

\begin{abstract}
The study was conducted in Ibadan, Southwest Nigeria to determine prevalence and predictors of contraceptive use, unwanted pregnancies and induced abortions among hairdressers. 1687 female hairdressers were surveyed using a cross sectional design

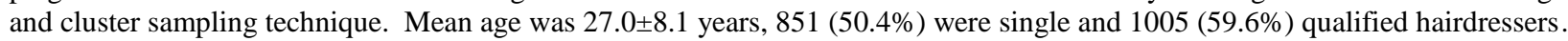
$817(56.8 \%)$ of sexually active were currently using contraception. Attainment of secondary school education was a predictor of contraceptive use; $\mathrm{OR}=1.4,95 \% \mathrm{CI}(1.1-1.8) .429$ (29.8\%) ever had an unwanted pregnancy; $26.5 \%$ among singles, $32.3 \%$ among married. Predictors of unwanted pregnancies were age >30years; OR=1.9, 95\% CI (1.4-2.5) and being a qualified hairdresser; OR=1.6, 95\% CI (1.2-2.2). 347 (24.1\%) ever had an induced abortion; $21.5 .0 \%$ of singles, $26 \%$ of married. Being married; OR=5.2, 95\% CI (2.2-11.9) was the only predictor of induced abortion. Prevalence of unwanted pregnancies and abortions were high especially among married hairdressers (Afr J Reprod Health 2017; 21 [1]: 114-121).
\end{abstract}

Keywords: contraception, female hairdressers, apprentices, induced abortion

\section{Résumé}

L'étude a été menée à Ibadan, au sud-ouest du Nigéria, pour déterminer la prévalence et les indices de l'utilisation de contraceptifs, des grossesses non désirées et des avortements provoqués chez les coiffeuses. 1687 coiffeuses ont participé à l'enquête à l'aide d'un modèle transversal et une technique d'échantillonnage en grappes. L'âge moyen était de 27,0 $\pm 8,1$ ans, $851(50,4 \%)$ étaient célibataires et $1005(59,6 \%)$ des coiffeuses qualifiées. 817 (56,8\%) des personnes sexuellement actives utilisaient actuellement la contraception. L'atteint de niveau de l'enseignement secondaire était un indice de l'utilisation de contraceptifs; OR = 1,4, IC à 95\% (1,1-1,8). 429 (29,8\%) ont eu une grossesse non souhaitée; 26,5\% chez les célibataires, 32,3\% chez les mariées. Les indices des grossesses non désirées étaient l'âge de plus de 30 ans; OU =1,9, IC 95\% $(1,4-2,5)$ et étant une coiffeuse qualifiée; OU = 1,6, IC à $95 \%(1,2-2,2)$. $347(24,1 \%)$ ont eu un avortement provoqué; $21,5 \%$ des célibataires, $26 \%$ des personnes mariées. Être marié; OU = 5.2, IC de 95\% (2.2-11.9) était le seul indice de l'avortement provoqué. La prévalence des grossesses et des avortements non désirés était particulièrement élevée chez les coiffeuses mariées (Afr J Reprod Health 2017; 21[1]: 114-121).

Mots-clés: contraception, grossesses non désirées, coiffeuses, avortement

\section{Introduction}

Female hairdressers are mostly young women in their reproductive years. The social environment of the hairdressing salon provides the opportunity to discuss sexual exploits among peers and this may easily influence decisions in respect of sexual behavior. Previous studies have shown that majority of single hairdressers engage in sexual activity $^{1}$. As a result of the low educational status of these women, they may be inadequately prepared to protect themselves from unwanted pregnancies and STIs including HIV/AIDS ${ }^{2}$.
The current emphasis on HIV with a single risk prevention approach may lead women to pay less attention to the risk of unwanted pregnancy and abortions ${ }^{3}$. Unwanted pregnancy is an important public health issue in developing countries like Nigeria because of the resulting adverse social and health outcomes. Studies have shown that one-third of women of reproductive age in Nigeria experienced unwanted pregnancies ${ }^{4-}$ 6 . The World Health Organization (WHO) estimates that one in five of the 210 million women who become pregnant each year worldwide resort to abortion ${ }^{7}$. The use of 
contraceptive methods reduces the rate of unwanted pregnancies and the need for unsafe abortion $^{8}$. Contraceptive prevalence in Nigeria is low with $15 \%$ of women in their reproductive years using some form of contraception ${ }^{9}$. In 2008, there were 28 abortions per 1,000 women aged 15-44 years in developing countries ${ }^{5}$. Bankole et al reported an abortion rate of $10 \%$ among all Nigerian women, $14 \%$ in Southern Nigeria and $16 \%$ among unmarried women ${ }^{10}$. A study in Ibadan reported that $18 \%$ of single hairdressers had ever had an abortion ${ }^{1}$. This abortion rate is higher than national and regional averages. There is a need to explore the factors associated with the occurrence of unwanted pregnancies and abortions among hairdressers in order to inform policies that will improve effective contraceptive use and enhance the reproductive health status of women in this occupational group.

\section{Methods}

The study was cross sectional in design and was carried out in Ibadan, Southwest Nigeria. Ibadan has about 2 million inhabitants whose major occupations are trading and artisanry in small scale enterprises ${ }^{11}$. Hairdressers, defined as individuals who cut or beautify hair, form a significant proportion of workers in artisan trades. They work in premises located in residential areas all over the city and are organized as a trade union, the Nigerian Beauticians and Hairdressers Association. Permission to carry out the study was obtained from the Hairdressers' Association and ethical approval was granted by the Oyo State Ministry of Health Ethical Review Committee.

A list of zonal groupings of hairdressing salons was obtained from the chairperson of the Hairdressers' Association in Ibadan. A cluster sampling technique was used to select fifteen zones out of an estimated fifty in the Ibadan metropolis by random sampling. The purpose of the study was explained to hairdressers at the zonal meetings in each zone. A list of hairdressing salons was provided by the chairperson of each zone. All salons registered with the zonal chairperson in the selected zones were visited. All hairdressers in the salons within the selected zones were eligible to participate in the study.
A structured questionnaire was used to collect information on demographic characteristics and occupational history of hairdressers, knowledge about contraceptive methods, and number of unwanted pregnancies ever had and experience of induced abortions. The questionnaire was pretested and modified before the commencement of the study to reduce any ambiguity or poor understanding of questions. It was translated into Yoruba, the local language, and back translated to English to check for correctness. Either the English or the Yoruba versions were used depending on the preference of the interviewee. The questionnaire was administered by trained research assistants after obtaining verbal informed consent from hairdressers and apprentices in each salon.

Dependent variables used in this study were current use of contraceptives, ever had unwanted pregnancies and ever had induced abortions. The WHO, NDHS and National HIV/AIDS and Reproductive Health Survey (NARHS) definitions were adopted ${ }^{12-14}$. Unwanted pregnancy was defined as a pregnancy that was not desired by the woman. Induced abortion was defined as the deliberate termination of a pregnancy, during the first 28 weeks. Contraceptive methods in this study included modern and traditional methods.

The independent variables were demographic characteristics assessed using the following indicators: age of respondents grouped as $\leq 30$ and $>30$ years; marital status grouped as 'never married' and 'ever married', highest level of education, classified as Junior Secondary School and below and Senior Secondary School and above and job grade categorized as apprentice hairdresser and qualified hairdresser.

\section{Data analysis}

The data were analysed with SPSS (Statistical Package for Social Sciences) software programme version 15 (SPSS 15.0 Command Syntax Reference 2006). Bivariate analysis was done to test for association between variables using the chi-square test. Multivariable logistic regression was used to identify independent factors associated with outcome variables; contraceptive 
Omokhodion \& Balogun

Table 1: Socio-demographic characteristics of respondents

\begin{tabular}{|c|c|c|}
\hline $\begin{array}{l}\text { Socio-demographic } \\
\text { characteristics }\end{array}$ & n $(\%)$ & $\mathrm{N}=1687$ \\
\hline \multicolumn{3}{|l|}{ Age group(years) } \\
\hline$\leq 30$ years & $1215(72.0)$ & \\
\hline$>30$ years & $472(28.0)$ & \\
\hline \multicolumn{3}{|l|}{ Religion } \\
\hline Christian & $1118(66.3)$ & \\
\hline Muslim & $563(33.4)$ & \\
\hline No response & $6(0.3)$ & \\
\hline \multicolumn{3}{|l|}{ Marital Status } \\
\hline Single/Never married & $851(50.4)$ & \\
\hline Married & $836(49.6)$ & \\
\hline \multicolumn{3}{|l|}{ Educational Status } \\
\hline Junior secondary and below & $391(23.2)$ & \\
\hline Senior secondary and above & $1296(76.8)$ & \\
\hline \multicolumn{3}{|l|}{ Job Grade } \\
\hline Apprentice hairdresser & $682(40.4)$ & \\
\hline Qualified hairdresser & $1005(59.6)$ & \\
\hline \multicolumn{3}{|l|}{ Years engaged as hairdresser } \\
\hline$<10$ years & 1207(71.6) & \\
\hline$\geq 10$ years & $451(26.7)$ & \\
\hline No response & $29(1.7)$ & \\
\hline
\end{tabular}

use, unwanted pregnancy and induced abortion. Variables significantly associated with outcome variables at $\mathrm{p}=0.05$ were included in the logistic regression model. The 'enter' option of the logistic regression in SPSS was used for variable selection where all variables in a block were entered in a single step. Odds ratios and their $95 \%$ confidence intervals were obtained. The level of significance for all tests was set at $5 \%$.

\section{Results}

A total of 1687 female hairdressers were interviewed comprising $682(40.4 \%)$ apprentices and $1005(59.6 \%)$ qualified hairdressers. Their ages ranged between 11 and 68 years with a mean age of 27.0 \pm 8.1 years. Majority $1215(72.0 \%)$ were aged 30years and above. 1118(66.3\%) were Christians and 563(33.4\%) were Muslims. Eight hundred and fifty-one (50.4\%) were single, $836(49.6 \%)$ were ever married. A total of $391(23.2 \%)$ had junior secondary education and below and $1296(76.8 \%)$ had at least secondary education. Most, 1207 (71.6\%) had been engaged
Reproductive Health Behavior of Hairdressers

in hairdressing for less than 10 years (Table 1).

Prevalence of contraceptive use, unwanted pregnancy and abortion

On the whole, 1438 (85.2\%) had ever had sex and a total of $604(71.0 \%)$ singles had ever had sex. Table 2 shows the sexual and reproductive health characteristics of sexually active respondents. One thousand one hundred and twenty-four respondents $(78.2 \%)$ had ever used a contraceptive method; $77.2 \%$ of singles and $79.0 \%$ of married respondents while 817 respondents $(56.8 \%)$ were currently using a contraceptive method at the time of the study; $59.7 \%$ of singles and $54.6 \%$ of married. One thousand and seventeen $(70.7 \%$ ) had ever been pregnant; $35.0 \%$ of singles and $96.6 \%$ of married. Four hundred and twenty-nine (29.8\%) had ever had an unwanted pregnancy; $26.5 \%$ singles and $32.3 \%$ married while 347 (24.1\%) had ever had an induced abortion; $21.5 \%$ of sexually active singles and $26.0 \%$ of married respondents. These differences were all statistically significant except for ever and current contraceptive use.

A total of $1623(96.2 \%)$ had ever heard of a contraceptive method. However, when asked about specific contraceptive methods, the male condom was the most known, reported by 1630 (96.6\%), while foam/jelly was least known by $158(9.4 \%)$. Table 3 shows that overall; the male condom was the most used contraceptive method by $395(23.6 \%)$ respondents. Use of withdrawal method 189 (11.2\%), injectables 89 (5.3\%), emergency contraception 63 (3.7\%), oral contraceptive pills 58 (3.4\%) and rhythm method $53(3.1 \%)$ were also reported. Female condom 1 $(0.1 \%)$ and foam/jelly $1(0.1 \%)$ were the least used. There were significant differences in the current use of some contraceptive methods between single sexually active and married respondents respectively: male condoms $(29.4 \%, 17.3 \%)$; injectables $(0.8 \%, 9.8 \%)$; pills $(1.5 \%, 5.4 \%)$; rhythm method $(1.8 \%, 4.5 \%)$; withdrawal method $(7.9 \%, 14.6 \%)$; intrauterine contraceptive device $(0.4 \%, 4.8 \%)$ and lactational amenorrhoea method $(0.1 \%, 1.4 \%)$. 
Table 2: Sexual and reproductive health characteristics of married and sexually active single respondents $\mathbf{N}=\mathbf{1 4 3 8}$

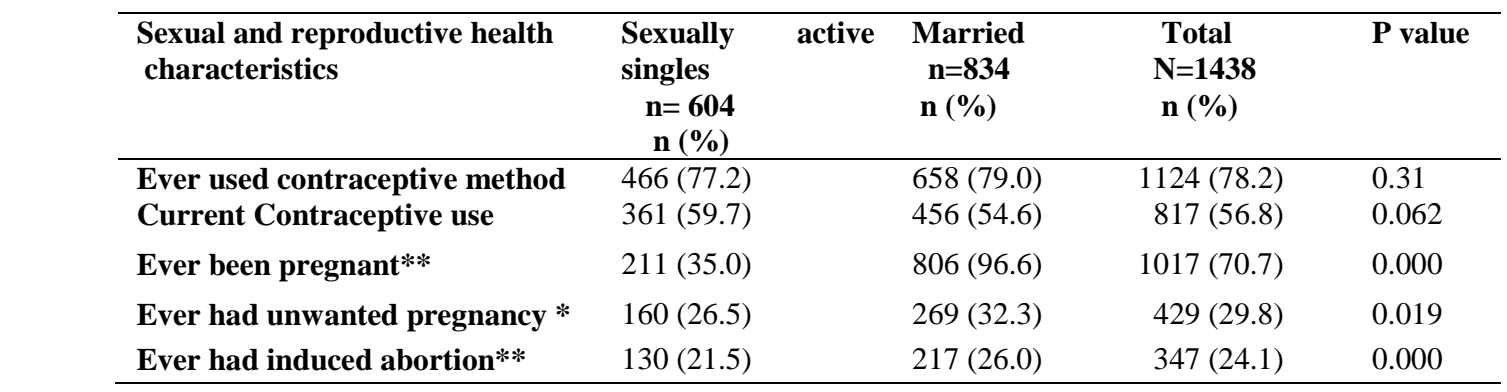

$* \mathrm{p}<0.05 * * \mathrm{p}<0.001$

Table 3: Contraceptive Method Currently Used by Respondents N=1687

\begin{tabular}{llll}
\hline Contraceptive method & $\begin{array}{l}\text { Single } \\
\mathbf{n}(\boldsymbol{\%})\end{array}$ & $\begin{array}{l}\text { Married } \\
\mathbf{n}(\boldsymbol{\%})\end{array}$ & $\begin{array}{l}\text { Total } \\
\mathbf{n}(\boldsymbol{\%})\end{array}$ \\
\hline Male Condom & $250(29.4)$ & $145(17.3)^{*}$ & $395(23.6)$ \\
Injectables & $7(0.8)$ & $82(9.8)^{*}$ & $89(5.3)$ \\
Oral contraceptive pills & $13(1.5)$ & $45(5.4)^{*}$ & $58(3.4)$ \\
Rhythm Method & $15(1.8)$ & $38(4.5)^{*}$ & $53(3.1)$ \\
Withdrawal method & $67(7.9)$ & $122(14.6)^{*}$ & $189(11.2)$ \\
Female condom & $0(0.0)$ & $1(0.1)$ & $1(0.1)$ \\
Intrauterine Contraceptive Device & $3(0.4)$ & $40(4.8)^{*}$ & $43(2.5)$ \\
Lactational Amenorrhoea Method & $1(0.1)$ & $12(1.4) *$ & $13(0.8)$ \\
Female sterilization & $0(0.0)$ & $1(0.1)$ & $2(0.1)$ \\
Implants & $0(0.0)$ & $4(0.5) *$ & $4(0.2)$ \\
Ring method & $0(0.0)$ & $2(0.2)$ & $2(0.1)$ \\
Emergency contraception & $37(4.3)$ & $26(3.1)$ & $63(3.7)$ \\
Chain & $0(0.0)$ & $2(0.2)$ & $2(0.1)$ \\
Armlets & $0(0.0)$ & $2(0.2)$ & $2(0.1)$ \\
Diaphragm & $0(0.0)$ & $2(0.2)$ & $2(0.1)$ \\
Foam/Jelly & $0(0.0)$ & $1(0.1)$ & $1(0.1)$ \\
\hline $\mathrm{p}<0.05$ & & &
\end{tabular}

\section{Predictors of unwanted pregnancy, abortion and contraceptive use}

Table 4 presents the predictors of the main outcome measures of the study; current use of contraceptives, ever been pregnant, ever had unwanted pregnancy and ever had induced abortions. Results for all sexually active women single and married are presented. The only predictor of current use of contraceptive method was attainment of secondary school education; $\mathrm{OR}=1.4,95 \% \mathrm{CI}(1.1-1.8)$. Predictors of ever been pregnant were age >30years; OR $=2.8,95 \%$ CI (1.5-4.9), being married; OR=26.0, 95\% CI (16.439.7) and being a qualified hairdresser; $\mathrm{OR}=2.4$, 95\% CI (1.7-3.4). Predictors of unwanted pregnancies were age >30years; OR $=1.9,95 \% \mathrm{CI}$ (1.4-2.5) and being a qualified hairdresser;
$\mathrm{OR}=1.6,95 \%$ CI (1.2-2.2). Married hairdressers were more likely to have ever had induced abortions, OR=5.2., 95\% CI (2.2-11.9).

Table 5 shows the results for sexually active single hairdressers only. The only predictor of current use of contraceptive method was attainment of secondary school education; $\mathrm{OR}=1.9,95 \% \mathrm{CI}$ (1.2-2.9). Predictors of ever been pregnant were age >30years; $\mathrm{OR}=4.2,95 \% \mathrm{CI}$ (1.8-9.7), and being a qualified hairdresser; $\mathrm{OR}=2.6,95 \% \mathrm{CI}(1.8-3.8)$. Predictors of unwanted pregnancies were age >30years; OR $=2.1,95 \% \mathrm{CI}$ (1.01-4.4), and being a qualified hairdresser; $\mathrm{OR}=1.9,95 \%$ CI (1.3-2.8). None of the tested variables were significantly associated with experience of induced abortion.

Among married hairdressers, the predictor of unwanted pregnancies was age $>30$ years; $\mathrm{OR}=1.9$, 
Table 4:Multiple logistic regression of factors associated with reproductive health variables in all sexually active respondents $\mathrm{N}=1440$

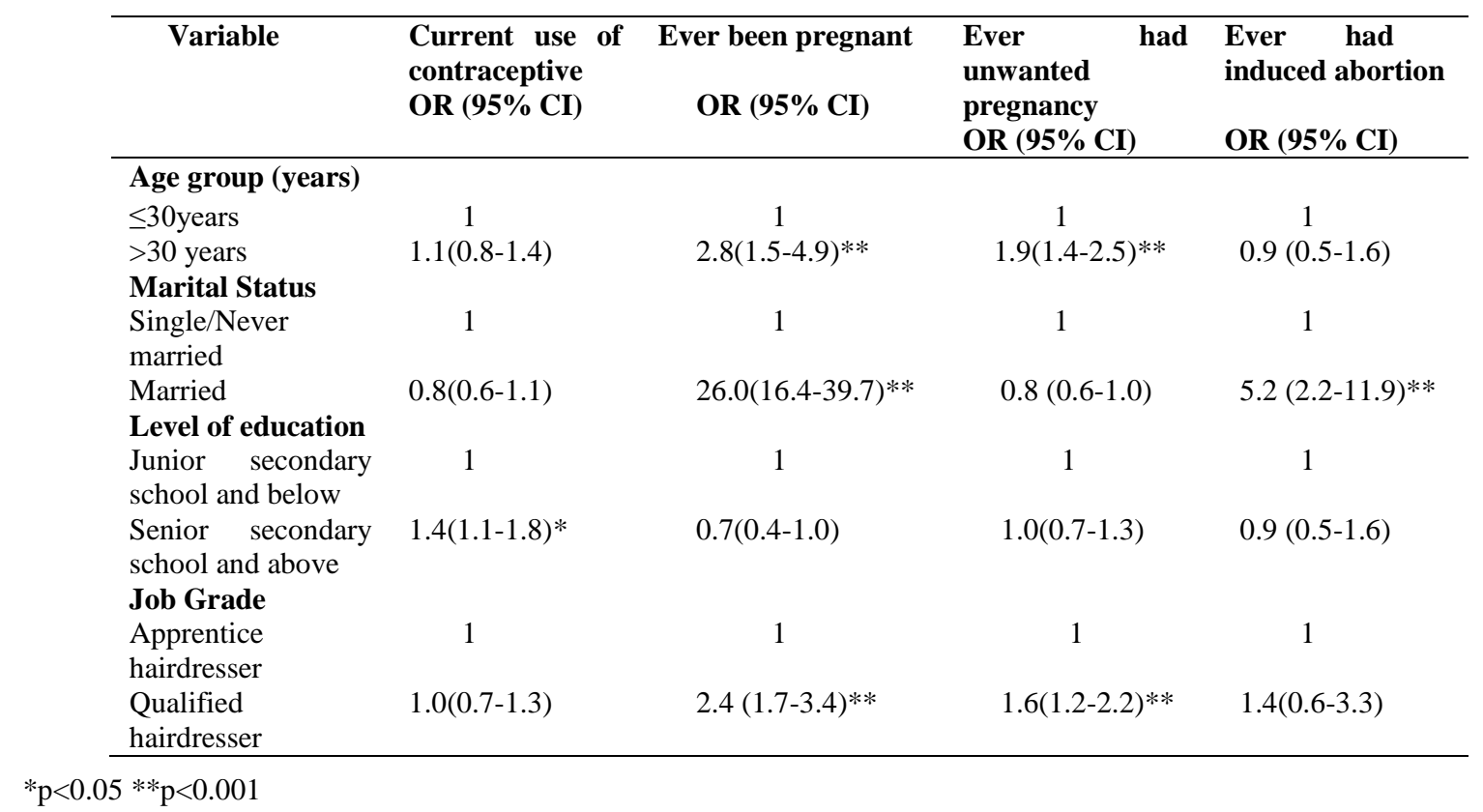

Table 5: Multiple logistic regression of factors associated with reproductive health variables of single sexually active hairdressers $\mathrm{N}=612$

\begin{tabular}{|c|c|c|c|c|}
\hline Variable & $\begin{array}{l}\text { Current use } \\
\text { of } \\
\text { contraceptive } \\
\text { OR }(95 \% \text { CI }) \\
\end{array}$ & $\begin{array}{l}\begin{array}{l}\text { Ever } \\
\text { pregnant }\end{array} \\
\text { OR }(95 \% \mathrm{CI}) \\
\end{array}$ & $\begin{array}{ll}\text { Ever } & \text { had } \\
\text { unwanted } & \\
\text { pregnancy } & \\
\text { OR }(95 \% \mathrm{CI}) & \\
\end{array}$ & $\begin{array}{l}\begin{array}{l}\text { Ever had } \\
\text { induced abortion }\end{array} \\
\text { OR }(95 \% \mathrm{CI}) \\
\end{array}$ \\
\hline \multicolumn{5}{|l|}{ Age group (years) } \\
\hline $\begin{array}{l}\leq 30 \text { years } \\
>30 \text { years }\end{array}$ & $\begin{array}{c}1 \\
1.3(0.6-2.7)\end{array}$ & $\begin{array}{c}1 \\
4.2(1.8-9.7)^{*}\end{array}$ & $\begin{array}{c}1 \\
2.1(1.0-4.4)^{*}\end{array}$ & $\begin{array}{c}1 \\
2.0(0.3-11.5)\end{array}$ \\
\hline $\begin{array}{l}\text { Level of education } \\
\text { Junior secondary } \\
\text { school and below }\end{array}$ & 1 & + & 1 & 1 \\
\hline $\begin{array}{l}\text { Senior secondary } \\
\text { school and above } \\
\text { Job Grade }\end{array}$ & $1.9(1.2-2.9)^{*}$ & & $1.6(0.9-2.7)$ & $1.3(0.1-12.4)$ \\
\hline Apprentice hairdresser & 1 & 1 & 1 & 1 \\
\hline Qualified hairdresser & $0.9(0.6-1.3)$ & $2.6(1.8-3.8)^{*}$ & $1.9(1.3-2.8)^{*}$ & $5.0(0.6-43.2)$ \\
\hline
\end{tabular}

${ }^{*} \mathrm{p}<0.05$

+ Not significant on bivariate analysis

95\% CI (1.4-2.6). No other socio-demographic variable was significantly associated with current use of contraceptive, ever been pregnant or ever had induced abortion, Table 6 .

\section{Discussion}

Majority of hairdressers in this study were sexually active. Almost all respondents had heard about a contraceptive method. This is comparable to reports by other researchers ${ }^{15-16}$. In spite of their awareness of contraceptive methods, about twothirds of respondents had ever used any and 57\% of them were currently using a contraceptive method at the time of the study even though $85 \%$ of them were sexually active. Current use of contraceptives was however higher than the national contraceptive prevalence rate of $15 \%$ and 
Table 6: Multiple logistic regression of factors associated with reproductive health variables of married hairdressers $\mathrm{N}=\mathbf{8 3 6}$

\begin{tabular}{lcc}
\hline \multicolumn{1}{c}{ Variable } & $\begin{array}{l}\text { Ever had } \\
\text { unwanted } \\
\text { pregnancy } \\
\text { OR (95\% CI) }\end{array}$ & $\begin{array}{l}\text { Ever had } \\
\text { induced } \\
\text { abortion } \\
\text { OR (95\% CI) }\end{array}$ \\
\hline $\begin{array}{l}\text { Age group (years) } \\
\leq 30 \text { years } \\
>30 \text { years }\end{array}$ & 1 & 1 \\
$\begin{array}{l}\text { Level of education } \\
\text { Junior secondary } \\
\text { school and below }\end{array}$ & $1.9(1.4-2.6)^{* *}$ & $0.9(0.5-1.5)$ \\
$\begin{array}{l}\text { Senior secondary } \\
\text { school and above }\end{array}$ & $0.8(0.6-1.1)$ & $0.9(0.5-1.6)$ \\
$\begin{array}{l}\text { Job Grade } \\
\text { Apprentice } \\
\text { hairdresser } \\
\text { Qualified hairdresser }\end{array}$ & $1.1(0.7-1.8)$ & \\
\hline$* * p<0.001$ & & 1 \\
\end{tabular}

regional prevalence rate of $32 \%$ in the southwestern region of Nigeria where the hairdressers were situated ${ }^{13}$. The overall contraceptive use prevalence is however lower than that reported among women in Zimbabwe (59\%), Egypt $(60 \%)$, and Algeria $(61 \%)^{17}$. Over half of the single sexually active hairdressers were currently using contraceptives. A high contraceptive use rate has been reported among singles ${ }^{13}$. The male condom was the mostly known and used contraceptive method, similar to results of the NDHS 2008 and $2013^{13,9}$ and that of other researchers ${ }^{1,18}$. Apart from its contraceptive function the male condom provides the additional advantage of protection from sexually transmitted diseases $^{8}$. It is notable that whilst the use of female condom can be initiated by women and also helps to protect against both pregnancy and sexually transmitted infections, it was the least used in this female population. Intervention programmes should be geared towards increasing awareness of the female condom, its use and benefits.

Respondents who had at least secondary school education were more likely to use a contraceptive method. This finding is corroborated by NDHS $2008^{13}$ and $2013^{9}$, NARHS ${ }^{14}$ and other researchers ${ }^{10,18}$ who reported that contraceptive use increased with level of education. Those with higher level of education are more likely to have access to information on contraceptive methods and sources of family planning services thus influencing their use.

Though contraceptive prevalence among hairdressers was higher than National figures ${ }^{13}$ unwanted pregnancies was $29.8 \%$, similar to findings of other researchers. Overall prevalence of unwanted pregnancy was $24 \%$ among women in both Ethiopia and Kenya and $26 \%$ in $\operatorname{Iran}^{19-21}$. In Nigeria, about one-fourth of women in a study conducted in eight states reported unwanted pregnancy $^{22}$. Similarly, Oye-Adeniran et al reported that $26.6 \%$ of women in Southwestern Nigeria had unwanted pregnancy at some point in their lives ${ }^{4}$. It is noteworthy that married women in our study reported a prevalence of unwanted pregnancy of $32 \%$. This was much higher than $13 \%$ reported for married women in both Kenya and Eastern Sudan ${ }^{20,23}$. The findings suggest that hairdressers may be at increased risk of unwanted pregnancies.

In many cases, unwanted pregnancies result in abortion ${ }^{10}$. Overall, one quarter of all sexually active women and $20 \%$ of all women in this study ever had an induced abortion. This is much higher than the estimated abortion rate of 28 per thousand for women in the reproductive age group in West Africa ${ }^{5}$ and twice as high than $10 \%$ abortion rates in all women in Nigeria ${ }^{10}$. In this study induced abortion rates among sexually active singles was $21.5 \%$. Higher abortion rates among singles have been reported in Nigerian literature. An abortion rate of $47.2 \%$ was reported among undergraduates in Port-Harcourt ${ }^{24}$ and $63.5 \%$ among students of tertiary educational institutions in Ilorin $^{15}$. However, unwanted pregnancy and abortion rates have been reported to be higher among women who are young, unmarried and still in school ${ }^{10,20,22,25}$. In a study conducted in eight states of Nigeria, women who had secondary or university-level education reported being too young or not wanting to interrupt their schooling as their primary reason for seeking abortion ${ }^{22}$. This may explain why undergraduates reported more abortion than hairdressers in this study. The abortion rate among sexually active single hairdressers cannot be compared with these studies because hairdressers are mainly out of school youths. 
Among sexually active single respondents, those who were older, qualified, with at least secondary school education currently used contraceptive methods, were ever pregnant and had unwanted pregnancies. This is probably because they have had longer periods of being single and more opportunities to engage in sexual intercourse.

Married hairdressers were more likely to have unwanted pregnancies and induced abortions than their single counterparts. This is contrary to findings by other researchers ${ }^{5,20,22,25}$. High rates of unwanted pregnancies may be due to a lower contraceptive use rate among married hairdressers in this study. The higher abortion rates among married hairdressers need to be further explored. Focus group discussions could help to unravel the factors that underlie these findings.

This study has some limitations. The use of contraceptive methods during the time unwanted pregnancy was conceived was not elicited. There could also have been underreporting of induced abortions among respondents due to the stigma associated with abortion because it is illegal in Nigeria.

\section{Conclusion}

This study identified a high level of awareness of contraceptive methods among hairdressers and high prevalence rates of unwanted pregnancies and induced abortions among married hairdressers. We conclude that female occupational groups should be provided with reproductive health education including information on effective contraceptive methods. For hairdressers in particular, intervention programmes should be geared towards improving contraceptive use to prevent unwanted pregnancies and abortions.

\section{Acknowledgement}

The authors are grateful to Physicians for Social Responsibility (PSR-Finland) for supporting this work as part of the monitoring and evaluation activities of a development cooperation project. We are also grateful to the hairdressers for their commitment and participation in the study.

\section{Declaration of Conflict of interest}

We declare no potential conflicts of interests with respect to authorship and/or publication of this article.

\section{Contribution of Authors}

FO conceived and designed the study. MB supervised data collection and did data analysis. Manuscript was prepared and approved by both $\mathrm{FO}$ and $\mathrm{MB}$.

\section{References}

1. Omokhodion FO, Onadeko MO, Balogun OO Contraceptive use among hairdressers in Southwest Nigeria Journal of Obstetrics and Gynaecology 2007; 27(6): 612-614

2. Guttmacher Institute 2012. Facts on Induced abortion. http://www.guttmacher.org/pubs/fb_IAW.html\#1a (Accessed 23rd October 2013).

3. Bajos N, Warszawski J, Greny I, Ducot B. AIDS and contraception. Unanticipated effect of AIDS prevention campaigns. Eur $J$ Public Health 2001;11(3):257-9

4. Oye-Adeniran BA, Adewole IF, Umoh AV, Ekanem EE, Gbadegesin A, Iwere N. Community-based survey of unwanted pregnancy in southwestern Nigeria. Afr J Reprod Health. 2004;8(3):103-15.

5. Sedgh G, Singh S, Shah IH, Ahman E, Henshaw SK,

Bankole A. Induced abortion incidence and trends worldwide from 1995 to 2008: Lancet, 2012379 (9816): 625-32

6. Okereke CI. Assessing the prevalence and determinants of adolescents' unintended pregnancy and induced abortion in Owerri, Nigeria. J Biosoc Sci. 2010; 42(5):619-32. doi: 10.1017/S0021932010000179. Epub 2010 Jun 3.

7. WHO. Unsafe abortion. Global and regional estimates of the incidence of unsafe Abortion and associated mortality in 2008

8. WHO, 2013. Fact sheet on Family Planning. http://www.who.int/mediacentre/factsheets/fs351/en /(Accessed 24th February 2014)

9. NDHS. Nigeria Demographic and Health Survey 2013. Preliminary Report. National Population Commission (NPC) [Nigeria] and Measure DHS, ICF International. Calverton, Maryland, USA.

10. Bankole A, Sedgh G, Oye-Adeniran BA, Adewole IF, Hussain R, Singh S. Unwanted Pregnancy and Induced abortion in Nigeria: Causes and Consequences, New York: Guttmacher Institute, 2006

11. National Population Commission. 2006. Final results of 


\section{Omokhodion \& Balogun}

2006 population census of Nigeria. http://www.population.gov.ng/ (Accessed 29th October 2014)

12. WHO, 2002. The World Health Report 2002 - Reducing Risks, Promoting Healthy Lives www.who.int/whr/2002/chapter4/en/index5.html (Accessed 24th February 2014)

13. NDHS. Nigeria Demographic and Health Survey 2008. National Population Commission (NPC) [Nigeria] and ICF Macro. 2009. Abuja, Nigeria

14. NARHS 2007. Federal Ministry of Health [Nigeria] (2008). National HIV/AIDS and Reproductive Health Survey, 2007 (NARHS Plus). Federal Ministry of Health Nigeria.

15. Abiodun OM, Balogun OR. Sexual activity and contraceptive use among young female students of tertiary educational institutions in Ilorin, Nigeria. Contraception. 2009;79(2):146-9. doi: 10.1016/j.contraception.2008.08.002. Epub 2008 Nov 17.

16. Krakowiak-Redd D, Ansong D, Otupiri E, Tran S, Klanderud D, Boakye I, Dickerson T, Crookston B. Family planning in a sub-district near Kumasi, Ghana: side effect, fears, unintended pregnancies and misuse of a medication as emergency contraception. Afr J Reprod Health. 2011; 15(3):121-32.

17. UNICEF 2014. The State of the World's children 2014 in numbers. Every child counts. Revealing disparities, advancing children's rights www.unicef.org/eapro/EN-FINAL_FULL_ REPOR T.pdf (Accessed 14th August 2014)

18. Asekun-Olarinmoye E1, Adebimpe W, Bamidele J, Odu $\mathrm{O}$, Asekun-Olarinmoye I, Ojofeitimi E. Barriers to

\section{Reproductive Health Behavior of Hairdressers}

use of modern contraceptives among women in an inner city area of Osogbo metropolis, Osun state, Nigeria. Int J Womens Health. 2013 11; 5:647-55. doi: 10.2147/IJWH.S47604. eCollection 2013.

19. Habte D Teklu S, Melese T, Magafu MG. Correlates of unintended pregnancy in Ethiopia: results from a national survey. PLoS One. 2013 9;8(12): e82987. doi: $0.1371 /$ journal.pone.0082987. eCollection 2013.

20. Ikamari L, Izugbara C, Ochako R. Prevalence and determinants of unintended pregnancy among women in Nairobi, Kenya. BMC Pregnancy Childbirth. 2013 19; 13:69. doi: 10.1186/14712393-13-69.

21. Najafian M, Karami KB, Cheraghi M, Mohammad Jafari R. Prevalence of and some factors relating with unwanted pregnancy, in Ahwaz city, Iran, 2010. ISRN Obstet Gynecol. 2011; 2011:523430. doi: 10.5402/2011/523430. Epub 2011 Oct 27

22. Sedgh G, Bankole A, Oye-Adeniran B, Adewole IF, Singh S, Hussain R. Unwanted pregnancy and associated factors among Nigerian women. Int Fam Plan Perspect. 2006;32(4):175-84.

23. Ali AA, Okud A. Factors affecting unmet need for family planning in Eastern Sudan. BMC Public Health. 2013 4; 13:102. doi: 10.1186/1471-2458-13-102.

24. Oriji VK, Jeremiah I, Kasso T. Induced abortion amongst undergraduate students of University of Port Harcourt. Niger J Med. 2009; 18(2):199-202.

25. Rabiu KA, Omololu OM, Ojo TO, Adewunmi AA, Alugo BG. Unsafe abortion in Lagos, Nigeria: a continuing tragedy. Niger Postgrad Med J. 2009; $16(4): 251-5$ 